Dialogos

\title{
Genealogy and Subjectivity: An Incoherent Foucault (A Response to Calvert-Minor)
}

Brian Lightbody

The essay "Archaeology and Humanism: An Incongruent Foucault" argues, among other things, that Foucault "endorses a kind of humanism." Moreover, Calvert-Minor attempts to show that without such an endorsement then the curative aspects regarding Foucault's genealogy of subjectivity would be nonsensical. To be sure, the author seems to demonstrate that there is a clear tension in Foucault's oeuvre regarding the Frenchman's changing stance towards, and at times unconscious embracement of, philosophical humanism. Such a claim, if true, would certainly be damaging to Foucault's archaeological and genealogical projects as he stridently rejected humanism in all of its myriad forms.

What makes this paper interesting is that it claims that Foucault backslides into two different humanistic positions with respect to at least two of the three principal periods of his work. In this respect, the paper seems to be on the other side of the fence with regard to some recent work in the secondary literature which has also sought to show Foucault's conscious avowal of humanism. For example, Eric Paras argues in his seminal work, Foucault 2.0: Beyond Power Knowledge, that Foucault comes to embrace, quite consciously, many key elements of humanism in his late work. Paras, however, seems to suggest that such humanistic leanings are the direct result of the epistemic and ontological aporias Foucault found himself in at the conclusion of his power/knowledge period and, as such, these leanings were conscious admissions by Foucault that his power/knowledge period explanation of subject formation was in drastic need of revision. ${ }^{1}$ Calvert-Minor however, unlike Paras, does not let Foucault off the hook, as it were, and charges Foucault with epistemic and ontological incongruency; a charge that, in my view, is off the mark. Rather, the true problem is much deeper: it is the charge of incoherency that is more appropriate.

For the purposes of space, I shall limit my essay to the third section of Calvert-Minor's work as I think this part is the most interesting and fecund. But, before examining Calvert-Minor's arguments in any further detail, I would like to flesh out why, precisely, Foucault's seemingly clandestine humanism is

${ }^{1}$ See Eric Paras, Foucault 2.0: Beyond Power/Knowledge (New York: Other Press, 2006). 
so deleterious to his overall philosophical project. Filling out the context regarding Foucault's contempt for humanism which I seek to do here is something that Calvert-Minor does not do (perhaps because of space constraints), but is absolutely necessary in order to bring his very criticism into sharper relief.

Foucault's anti-humanism emerges perennially throughout his work. For example, in The Order of Things, Foucault suggests that 'Man' is an invention; an arbitrary weaving of the discourses of labour, life, and language. This transcendental-empirical doublet, as Foucault calls it, becomes the starting point not only for the human sciences, but indeed even for that most abstract science of man: phenomenology. However, these 'knowledges' of man have built their edifices, unbeknownst to them, on shifting sands: the ultimate substratum of the social sciences (and even phenomenology) are built on something which is ungraspable; some 'thing' which has no clear essence. ${ }^{2}$

'Man' is without essence because it is a purely historical construct. Foucault's point, crudely put, is that since the investigative starting point of the social sciences is necessarily historical, contingent and arbitrary then the truths revealed must also be contingent, arbitrary, and historical as well. Such an epistemic foundation would not be terribly troublesome for other methods of philosophical investigation, like genealogy for example, because genealogy does not pretend to be objective: in fact it eschews any and all attempts to arrive at so called "objective" knowledge. But, for the human sciences, this point is deeply disconcerting because such sciences have traditionally attempted to discover the inner wellsprings of mankind. Yet, what Foucault shows, in a mere 100 pages of text, is that these same "sciences" are destined to spin their wheels in the sands of history always failing to get the ontological traction they so desperately desire. Calvert-Minor ends section two of his paper by ably explaining the myriad of problems with what Foucault calls "Man's doubles" in striking clarity.

Foucault remains critical of humanism in his later work. This time, however, Foucault's attacks are less esoteric and more concrete. The "late" Foucault targets the many political and social dangers that have emerged from a hyper-concern we might say for 'humanity.' In "What is Enlightenment?" for example, he demonstrates how even the very term "humanism" is both conceptually and morally bankrupt. ${ }^{3}$ Foucault identifies two problems with any movement which purports to 'save' humanity (which I think those who call themselves "humanists" seek to do). Whether humanity is here interpreted metaphorically in terms of the essence of humanity as it were or more concretely in terms of saving human civilization as a whole, humanists, of both stripes, are subject to the same two criticisms which Foucault elucidates in this fecund essay. The first problem Foucault identifies has to do with the vagaries of humanism. Humanism is just too vague a concept to do any real

\footnotetext{
2 See Michel Foucault, The Order of Things: An Archaeology of the Human Sciences (Vintage Books: 1970), 250-344.

3 See Michel Foucault, "What is Enlightenment?," in The Foucault Reader, ed. by Paul Rabinow and trans. by Catherine Porter (New York: Pantheon Books, 1990).
} 


\section{0}

GENEALOGY AND SUBJECTIVITY

philosophical or moral work. It simply lacks substance. Such questions like, "What is man?" or "What is the human qua human?" Are questions that many philosophers and even some humanistic scientists (such as Comte and Bentham) have tried to answer over the centuries, but without much success. However, since the concept is so open to differing interpretations, Foucault contends, this allows it to be used and abused by any individual, group or political party (like National Socialism for example) for the most inhuman of goals.

But the second problem with the term is that it seems to contain what Eric Vogelin might call Neo-Gnostic elements. Vogelin has humanism in mind when he persuasively argues in The New Science of Politics that,

Gnosis may be primarily intellectual and assume the speculative penetration of the mystery of creation and existence, as, for instance, in the contemplative gnosis of Hegel or Schelling. Or it may be primarily emotional and assume the form of an indwelling of divine substance in the human soul, as, for instance, in paraclectic sectarian leaders. Or it may be primarily volitional and assume the form of an activist redemption of man and society, as in the instance of revolutionary activists like Comte, Marx or Hitler. ${ }^{4}$

It is questionable whether Foucault read Vogelin. But what is clear is that Foucault makes very similar points to those raised by Vogelin regarding the dangers of humanism. Such dangers are advanced, albeit in embryonic form, in the famous Chomsky-Foucault debate of 1971. In that debate, Foucault stresses caution with respect to adopting a political position which is ultimately subtended on an immutable concept of what it means to be "human." In essence, he reminds Chomsky that the words "human" and "humanism" are not merely descriptive terms. They have normative inflections. And, because they have normative inflections they carry with them the push/pull mechanics of ought/should statements. ${ }^{5}$ As Vogelin clearly explains and as Foucault intimates in the debate, Neo-gnostics, even if well meaning, are not satisfied in simply "pulling back the curtain" as it were in order to reveal the true, immutable, timeless design of humanity and human civilization. They are only satisfied when this vision is realized. While those who stand in the way to this vision materializing are likewise considered to be "enemies" of humanism. ${ }^{6}$

168.

${ }^{4}$ Eric Vogelin, The New Science of Politics (Chicago: University of Chicago Press, 1952),

5 See Arnold I. Davidson ed., Foucault and His Interlocutors (Chicago: University of Chicago Press, 1997).

${ }^{6}$ For more on the Chomsky-Foucault Debate see my paper, "Theseus vs. The Minotaur: Finding the Common Thread in the Foucault-Chomsky Debate" in Studies in Social and Political Thought, 8 (May 2003), 67-84. 
Foucault desperately tries to illuminate the mistake that many well intended humanists commit when they seek to define what precisely makes a human a human in his debate with Chomsky. The problem, in brief, is that when we circumscribe what it means to be "human" we leave out that which is non-human. ${ }^{7}$ This circumscription of what is taken to be human may become dangerous because that which is non-human is then very often considered to be beyond the pale (both morally, politically ontologically). But, because it is outside of us it becomes Other to us and, therefore, some unknown thing which is inherently different, dangerous, and, perhaps, evil.

I have decided to add all of this in order to place Calvert-Minor's views in greater context: to see more perspicuously what precisely is at stake in this debate and why Foucault's attacks on humanism are so trenchant and vitriolic at times. In sum, Foucault seems to contend that humanism is a very dangerous non-idea, a flatus vocis, that compels individuals to fight for some illdefined goal. Such revolutionary energies, Foucault evinces, may lead to even more suffering and could be put to better uses.

With this out of the way, I would now like to turn to Calvert-Minor's re-description of the term 'humanism' itself. The author breaks new ground in showing that humanism can be further analyzed and divided into two different types. For this, the author takes a page from philosophy of science circles. Very often philosophers will make a distinction between substantive naturalism, on the hand, and methodological naturalism, on the other. CalvertMinor shows that we may use this same distinction to redefine humanism into two different categories: methodological humanism (humanism $\mathrm{m}$ ) and substantive humanism (humanism s). ${ }^{8}$ As he explains, "Methodological humanism refers only to the process of unifying discourse or practices according to the consciousness of a human subject or subjects; human consciousness is the regulator of the process itself, rather than for example, structures that are out of our control." Substantive humanism according to the author "corresponds to those theories which emphasize the importance of humanity via some shared attribute or substance." Of course, the traditional conception of humanism is one of substantive humanism and it is this version which is far more philosophically robust and, I would argue, problematic for Foucault if he indeed does embrace humanism s.

Calvert-Minor clearly demonstrates that Foucault lapses into humanism $\mathrm{m}$ throughout most of his archaeological work. This lapse has been well documented in the secondary literature. Dreyfus and Rabinow, Habermas and many others have all commented on the deeply disconcerting or indeed as Habermas puts it "impossible project" of archaeology. But, to his credit

\footnotetext{
${ }^{7}$ In fact, it is more true to say that this practice of circumscription does not begin by discovering those essential attributes of the human and then rejecting all those things which do not have these attributes. Rather the reverse is true: our conception of humanity is constructed by denying all of those aspects with which we wish not to be associated. Thus, just as rationality is constructed via negativa as Foucault clearly shows in Madness and Civilization so too humanism is also constructed.
} 


\section{GENEALOGY AND SUBJECTIVITY}

Calvert-Minor shows that one may make this exact same criticism as these dare I say Continental authors from the resources of Analytic Philosophy.

As others have also inferred and again as Paras most clearly shows with his careful sifting of archival work, Foucault too, it seems, came to a similar conclusion. Foucault also realized the epistemic problems and closet humanism, if you will, of his archaeological method. But Foucault's critique of his earlier work in the seventies was much deeper and penetrating than perhaps how it is presented in Calvert-Minor's essay. For it was, at this time, that Foucault came to immerse himself in the work of Nietzsche in order to find, as many philosophers have, a new way of philosophizing and a new way of being.

Of course, Foucault was already well versed in Nietzsche's corpus by 1970. But it seems that it was not until the publication of "Nietzsche, Genealogy, History" in 1971 that we see not only a profound understanding and indeed novel re-interpretation of Nietzsche's genealogical method, but a clear avowal, on Foucault's part, that he too would follow the path that Nietzsche had now opened to see where it might lead.

Perhaps the most striking aspect of genealogy is its affirmation of perspective. Nietzsche's perspectivism (or better perspectivalism) is an epistemic and ontological position which both places limits on what sort of knowledge is impossible for humans to attain as well the possible sorts of things that we can come to know. Yet these 'perspectives' which we may have on the world, Nietzsche makes clear, are not grounded upon any sort of nascent structures which we 'humans' instinctively have for ascertaining the truth nature of the world. Rather, such perspectives emerge simply from the Abgrund (abyss) of power itself. In other words, there is no bypokemenon beneath any of our most treasured and trusted concepts and that includes the most primary philosophical concept of all, namely, truth. All there is, all there can ever be, are the confluences of power. What precisely this last point entails is unfortunately glossed over at times in the secondary literature. Thankfully, Alasdair MacIntyre in his wonderfully lucid and magisterial "Three Rival Versions of Moral Inquiry" helps brings this point home. He writes:

The ruptures in that history (of science), as identified by Bachelard and Kuhn, moments in which a transition is made from one standardized understanding of what is to be rational to some other, sometimes incommensurable standardized understanding of rationality, are also secondary phenomena. For they, like the standardized orders which they divide and join, are the outcome of assemblages and confluences in the making of which distributions of power have been at work, in such a way that what appear at the surface level as forms of rationality both are, and the result from, the implementation of a variety of aggressive and defensive strategies, albeit strategies without subjects. Truth and power are thus inseparable. And what appears as projects 
aimed at the possession of truth are always willful in their exercise of power. ${ }^{9}$

At best we may trace the genealogical strands of such historical events as guilt, the ascetic ideal or the rise of the carceral regime, but we must remember that such tracings are merely that: tracings. We never get at the 'real' engines at work in history. Everything as Nietzsche and Foucault make clear is over-determined.

With this move, it becomes clear that archaeology, despite Foucault's protestations to the contrary, has a much more limited role to play in a genealogical investigation. To be sure it may play a role in understanding "regimes of truth", but such regimes are constituted by confluences of power which we can never fully grasp, but are at best diagrammed a la Deleuze. The body becomes the primary document for the genealogist, but the body is, as Foucault well understood, "a volume in perpetual disintegration." 10

Still, the true value of genealogy remains: it is the ultimate process of unmasking. And what does it reveal? One thing and one thing alone: power. The purpose of genealogy is to show that it is power and nothing but power that is at the root of our most prized and cherished ideals. However, this process is interminable: there can always be a genealogy of a genealogy. In sum, what is revealed is not a human face behind each mask, but merely another mask: one more hideous and grotesque than the one before.

So we now turn to what I think to be the heart of Calvert-Minor's paper, that is, whether the late Foucault embraces substantive humanism. In sum the author argues that if Foucault explicitly claims that some forms of life are better than others, then this would seem to imply that some forms are inherently better for humans than others. But, if this is true, then Foucault is claiming that certain features of human life-such as freedom-are intrinsically valuable because they are defining features of what makes human life valuable in and of itself regardless of the dispositif in which one finds themselves. That is, Foucault is claiming to know which forms of life are preferable for all humans based on some mysterious insight as to what makes a human qua human. But, Calvert-Minor claims, Foucault's anti-humanism stance forbids him from having this knowledge. Thus, in order to live a worthwhile life or at least one where the ebb and flow of power will be kept at a minimum, we must discover those essential features of human life which make our lives valuable. Therefore, in order for Foucault's project to be coherent, he must subscribe to a minimal, substance humanism. But with this admission, Calvert-Minor evinces, we have an incongruent Foucault.

While it is true that Foucault's later work tries to show that the true merits of genealogy lie in its ability to provide new ways of living, this does not

9 Alasdair MacIntyre, "Genealogies as Subversions," in Nietzsche, Genealogy, Morality, ed. by Richard Schacht (Berkeley: University of California Press, 1994), 284-306, 301.

10 Michel Foucault, "Nietzsche, Genealogy, History," in Language, Counter-Memory, Practice, trans. by Donald F. Bouchard and Sherry Simon (Ithaca: Cornell University Press, 1977) 139-165, 148. 


\section{GENEALOGY AND SUBJECTIVITY}

entail that some "modes of existence" are inherently superior to other modes. And it is this claim which Calvert-Minor needs to substantiate in order for his thesis to go through. I argue that the Calvert-Minor's argument is ultimately invalid because he makes two equivocations in his conclusion. The first is between two different conceptions of substantive humanism. Let us call the first, Absolutist, Substantive Humanism (ASH) and the second NonAbsolutist, Substantive Humanism (NASH). ASH, corresponds to those theories which emphasize the importance of humanity via some essential, immutable, shared attribute or substance. NASH, corresponds to those theories which emphasize the importance of humanity via some shared attribute or substance which is neither essential, nor immutable, but is often dynamic; our essence, as 'humans' changes based on the dispositif in which one finds themselves. The final question I wish to investigate is whether, by Calvert-Minor's own argument, he has proven that Foucault is an Absolutist Substantive Humanist or whether he is merely a Non-Absolutist Substantive one.

I think that it is obvious that Foucault and Nietzsche too, I might add, are humanists of the second type. Foucault, then, might very well emphasize "the importance of humanity" as the Calvert-Minor notes, but not because there is a substantive essence to the human being that needs to be safeguarded. Rather, the importance of 'humanity,' indeed the task of humanity as a whole might be to prevent any one form of 'humanity' from being crystallized by power/knowledge such that it becomes the only form that any buman can take. For, if such a crystallization became a reality, Foucault argues, then it becomes impossible to fight against power. Indeed, power would no longer be power because power, in Foucault's mind, is simply agon; struggle.

Now with that being said, it is arguable that Calvert-Minor already considered this point and yet may still maintain the novelty of his position. He could still coherently argue that Foucault falls into an ASH position since there must be, at minimum, a relatively stable ground that makes alternative, human forms of life possible. That is, since we are still referring to the possibility of there being different forms of humanity, then this would imply that each form has at least some thing in common because they are still modes of this one human essence; whatever that might be. And, to his credit, the author seems to recognize this when he writes,

If one assents to practices that are better or worse, more or less dangerous, one implies that there is a relative level of stasis in humanity that should be attained for the cultivation of a healthy subjectivity; one identifies a continuum of constructed subjectivities that mark out gradational categories of being that are more and less appropriate for humanity. But once there is an implication of what is appropriate for humanity, it requires a tacit conception of what humanity is, even if such a conception is vague and unformed. 
But with this passage, Calvert-Minor gives himself away for it is clear that Foucault is not working with a tacit conception of humanity at all. He is working with a tacit conception of subjectivity. And that is a much, much different conception. This last ditch effort to show Foucault's true humanistic stripes allows for the second case of equivocation as Calvert-Minor clearly conflates subjectivity with humanity. It is this conflation which renders his argument invalid. To be sure we often do use the term 'human' to describe subjects in ancient or medieval times, but they would not think of themselves as 'human' in the way that we employ this term with all of its biological, linguistic and other ontological trappings. They might conceive themselves as mortals, or as entrapped souls waiting for judgment etc., but this is a far cry from suggesting that these historical subjectivities are merely different modes of one common, though vague conception of humanity. It is clear from what I said above regarding the perspectival nature of power, that it is only from our corner of history, from our bio-political dispositif that causes us to project humanity or "human beingness" onto these historical subjects. Humanity remains, as Foucault already demonstrated in The Order of Things, as only one way of ordering things within history and perhaps one that is now nearing its end.

To be clear, I do think that Foucault, at times, is guilty of making the same conflation as the one made by Calvert-Minor. I think Foucault contradicts himself on numerous occasions. In any case, my attempt in this short essay has been to find a more charitable reading that allows Foucault to escape the charge of incongruency with respect to the question of Foucault's latent humanism.

Now with respect to Foucault's philosophy of subjectivity, it is much more difficult to find a charitable interpretation that would render Foucault's views regarding the relationship between power and resistance coherent. Indeed, as Taylor, Habermas, Fraser, Norris, Bernstein and many others have shown, Foucault's difficulty is one of squaring a substantive notion of subjectivity, as espoused in his late work, with the behaviorist or dressage view of subjectivity as evinced in his power/knowledge period. ${ }^{11}$ In brief, these thinkers demonstrate that the true problem with regard to Foucault's

${ }^{11}$ See Jurgen Habermas, The Philosophical Discourse of Modernity: Twelve Lectures, trans. by Frederick Lawrence (Cambridge Mass: MIT Press, 1987) 238-294. Also see Habermas' “Taking Aim at the Heart of the Present" in Foucault: A Critical Reader, ed. by David Couzens Hoy (New York: Blackwell, 1986). See Charles Taylor's "Foucault on Freedom and Truth" also in Foucault a Critical Reader, 69-103. Nancy Fraser, in her collection of essays entitled Unruly Practices, (Minneapolis, University of Minnesota Press, 1989) presents many articulate and penetrating criticisms of Foucault's ethical position. Christopher Norris has also argued along similar lines both in his earlier essay "What is Enlightenment? Kant according to Foucault" in The Cambridge Companion to Foucault (Cambridge University Press, 1994), 159-197 as well as his more recent article: "Ethics, Autonomy and Self-Invention: A Reply to Patrick Shaw," in Journal of the British Society for Phenomenology, 31:1 (January 2000), 92-103. Also see Richard Bernstein, "Foucault: Critique as a Philosophical Ethos," in Recasting the Foucault/Habermas Debate, ed. by Michael Kelly (Cambridge Mass: MIT Press, 1994). 


\section{GENEALOGY AND SUBJECTIVITY}

philosophy is that it is ultimately incoherent: resistance makes no sense unless both truth and freedom lie outside of power. And, although several recent books in the secondary literature have valiantly tried to bridge what seem to be two incommensurable views of subjectivity, nevertheless, I think their efforts have been in vain. Thus, Calvert-Minor's essay has brought Foucault up on a lesser and, really, trivial charge: incongruency is not a genuine problem with respect to Foucault's thought. Foucault has committed such seeming incongruencies time and time again. The true problem is one of incoherency. It is this charge which sticks.

Department of Philosophy, Brock University, Canada

\section{References}

Bernstein, Richard, "Foucault: Critique as a Philosophical Ethos," in Recasting the Foucault/Habermas Debate, ed. by Michael Kelly (Cambridge Mass: MIT Press, 1994).

Davidson, Arnold I. ed., Foucault and His Interlocutors (Chicago: University of Chicago Press, 1997).

Foucault, Michel, "Nietzsche, Genealogy, History," in Language, Counter-Memory, Practice, trans. by Donald F. Bouchard and Sherry Simon (Ithaca: Cornell University Press, 1977) 139-165. , "What is Enlightenment?" in The Foucault Reader, ed. by Paul Rabinow and trans. by Catherine Porter (New York: Pantheon Books, 1990).

, The Order of Things: An Archaeology of the Human Sciences (Vintage Books: 1970).

Fraser, Nancy Fraser, Unruly Practices, (Minneapolis: University of Minnesota Press, 1989).

Habermas, Jürgen, "Taking Aim at the Heart of the Present," in Foucault: $A$ Critical Reader, ed. By David Couzens Hoy (New York: Blackwell, 1986).

, The Philosophical Discourse of Modernity: Twelve Lectures, trans. by Frederick Lawrence (Cambridge Mass: MIT Press, 1987), 238-294.

Lightbody, Brian, "Theseus vs. The Minotaur: Finding the Common Thread in the Foucault-Chomsky Debate," in Studies in Social and Political Thought, 8 (May 2003), 67-84.

MacIntyre, Alasdair, "Genealogies as Subversions," in Nietzsche, Genealogy, Morality, ed. By Richard Schacht (Berkeley: University of California Press, 1994), 284-306.

Norris, Christopher, "Ethics, Autonomy and Self-Invention: A Reply to Patrick Shaw," in Journal of the British Society for Phenomenology, 31:1 (January 2000), 92-103.

, "What is Enlightenment? Kant according to Foucault," in The Cambridge Companion to Foucault (Cambridge University Press, 1994) 159-197. 


\section{B. LIGHTBODY 27}

Paras, Eric, Foucault 2.0: Beyond Power/Knowledge (New York: Other Press, 2006). Taylor, Charles, "Foucault on Freedom and Truth" also in Foucault a Critical Reader ed. By David Couzens Hoy (New York: Blackwell, 1986), 69103.

Vogelin, Eric, The New Science of Politics (Chicago: University of Chicago Press, 1952). 